Vol. 12, $n^{\circ} 1 \mid 2008$

Varia

\title{
Mysterious and Suspicious Deaths: Missing Homicides in North-West England (1850-1900)
}

John E. Archer

\section{OpenEdition}

Journals

Electronic version

URL: https://journals.openedition.org/chs/66

DOI: $10.4000 /$ chs.66

ISSN: 1663-4837

Publisher

Librairie Droz

Printed version

Date of publication: 1 April 2008

Number of pages: $45-63$

ISBN: 978-2-600-01237-9

ISSN: 1422-0857

\section{Electronic reference}

John E. Archer, "Mysterious and Suspicious Deaths: Missing Homicides in North-West England

(1850-1900)", Crime, Histoire \& Sociétés / Crime, History \& Societies [Online], Vol. 12, n | 2008, Online since 01 April 2011, connection on 22 March 2022. URL: http://journals.openedition.org/chs/66 ; DOI: https://doi.org/10.4000/chs.66

This text was automatically generated on 22 March 2022.

(c) Droz 


\section{Mysterious and Suspicious Deaths: Missing Homicides in North-West England (1850-1900)}

John E. Archer

\section{Historiographical Overview and Methodological Approaches}

1 Historians for many years questioned the value and veracity of criminal statistics, but have, for the most part, contended that those figures relating to murder have been the most accurate. Gurr, who acknowledged the existence of the 'dark figure' of unreported crime in his overview of historical trends in violent crime, argued that murder was and has been the most accurately reported crime because of its capacity to shock the public and the difficulty of concealment. In the famous and, some would argue, ill-tempered debate on declining violence in English society the protagonists, Stone, Sharp and Cockburn, accepted that murder was quantifiable and that statistics related to so serious a crime were accurate enough to draw conclusions about its long-term decline ${ }^{2}$.

More recent work by Howard Taylor has suggested that the English murder statistics may not be all that they seem ${ }^{3}$. By adopting, paradoxically, a statistical approach to his analysis of reported murders, Taylor uncovered what at first sight seems to be a strange and remarkable pattern. Between 1880 and 1966 the number of reported murders in England and Wales averaged 150 a year and any variation which occurred was within $20 \%$ of this average ${ }^{4}$. This pattern, which actually begins in 1862 , appeared anything but accidental and coincidental. Taylor's main explanation for the levelling of the murder figures is persuasive; namely the need to keep prosecution costs limited. Murders, he maintained, were rationed by the amount of money that was required to investigate and prosecute them. Critics have been slow to come forward and challenge such a provocative and controversial finding. Robert Morris, however, has raised two important issues which need to be confronted. First, the ability to control England and 
Wales' homicide figures in such a way would have required a conspiracy of enormous proportions; chief constables, senior police officers, coroners, and civil servants at the very least would have to have been in on the secret. It seems highly unlikely that either the secret could have been maintained for over 100 years without the press and public finding out or that it did not generate paper records which would eventually fall into the hands of inquiring historians. Second, the notion of the 150/year average with a possible swing of $20 \%$ either side of that figure actually implies, according to Morris, 'a remarkably high degree of volatility'. In other words the actual number of murders in this country ranged between 120 and 179 a year. This seems quite a wide variation ${ }^{5}$. Whether we accept Taylor's thesis or not, it cannot be denied that he has injected a new interest into the history of homicide in this country. One additional sub-theme within the history of homicide, raised by Monkkonen, Taylor, Morris and Emmerichs is the question of 'missing homicides', or what the Victorians newspapers headlined as 'mysterious' and 'suspicious deaths'. It is to this theme that this paper now turns 6 .

3 Historians working on documentary evidence are inevitably faced with a difficult and, at times, impossible task. From this distance over time they cannot take on the role of murder detective and solve these mysterious and suspicious deaths. But what they can do is identify deaths which were regarded as suspicious at the time but which do not appear to have been recorded by the police or coroners as murders or even as homicides. The methodology employed in this study in selecting which suspicious deaths to include was based on whether news items reported the use of violence or the possibility of violence having contributed to the death of the deceased. In order to identify such cases I have used newspapers from Liverpool and Manchester between 1850 and 1900 which carried reports from the coroners' courts in the two major cities, and in some cases accounts of possible crimes that remained mysterious and unresolved throughout the county of Lancashire. The Head Constables' Annual Criminal and Police Returns for both cities have also been consulted as these indicate murder and manslaughter cases known to the police and also the Liverpool Coroner's Registers between 1852 and 1865 for the earlier part of the period under review. Over the 50-year-period I have collected a sample of over 250 suspicious death and have discounted deaths that were, in all likelihood, cases of suicide, accidents and natural causes.

For of all the records and reports utilised I have found that discovering the contexts, circumstances and details of the deaths are important in forming judgements surrounding the cases. It became apparent to me that some of the judgements and conclusions arrived at by the various courts were surprising and required some kind of explanation. Determining what constituted a homicide - manslaughter and murder are the two main crimes under consideration here - was a long drawn out process of sifting the details of the deceased and, where one existed, any possible culprit ${ }^{7}$. By way of clarification concerning legal definitions; 'The difference between murder and manslaughter turns on the presence or absence of "malice aforethought"'. In other words murder either consisted of the intention to kill another person, or to do grievous bodily harm to that person. Manslaughter, on the other hand, was a non-capital offence that arose from a fatality in which no intention to kill was evident on the part of the defendant ${ }^{8}$.

5 Initially the enquiry into sudden and suspicious deaths began in the most ancient of Britain's courts, namely the coroner's court. Nineteenth-century Lancashire possessed 
up to five borough coroners' courts, with Liverpool and Manchester possessing fulltime appointees, whilst the wider county had between six and seven elected part-time officials. The coroner had to enquire into all sudden and unexpected deaths within his jurisdiction and, where necessary, conduct inquests in which medical evidence was presented to a jury who decided on the cause of death. Evidence was examined, often very speedily, in the coroner's court and the verdict reached by the jury would invariably dictate how the police might subsequently handle the case ${ }^{9}$. Open verdicts, where the court was uncertain of the cause of death, could often be reason enough for the police to end their own separate enquiries. On the other hand, coroners' court murder verdicts led to further investigation by the police which might then lead to a full trial at the county assize court. Invariably the number of murder verdicts reached by coroners' courts exceeded the number of reported murders submitted by the police in their annual returns. In 1863 for example there were 11 murders known to the Liverpool constabulary whereas the coroner's court reported $16^{10}$.

6 This disparity in the figures suggests that a closer examination of how crime statistics were constructed is necessary. In Liverpool for example, head constable Greig reported in 1866:

In comparing the cases of murder with those of the Coroner's return, the apparent difference in number arises from the police returning the cases after they are tried at the Assizes, where the real character of the offence is determined, whilst those in the Coroner's Return are the finding of the Jury upon the inquest ${ }^{11}$.

7 But where the police had made no arrests the head constable had stated a year earlier, 'it becomes a matter of opinion whether the crime would be proceeded against by indictment or otherwise ${ }^{12}$. This meant that the murders could be left out of the annual returns if, in the opinion of the head constable, the police would have had trouble in winning a conviction in the assize court. One wonders how uniform this reporting practice was around the country. Any disparities could have skewed the national annual murder total as well as the separate police authorities' crime figures. However the Liverpool reporting methods would have had the added benefit with regard to one of the criteria for defining police efficiency, namely low reported crime. The 'matter of opinion' directive also gave the police enormous discretion in defining murder, for example in Liverpool recorded murders rose from 6 cases/year in 1867 to 27 in 1868, dropping slightly to 20 in 1869 before returning to a more usual 10 cases a year in $1870^{13}$. This huge increase in reported murders is examined more closely below. However, we might note that historians who rely solely on quantifying methods may be seriously misled.

\section{Infanticide}

8 When dealing with homicide in all its different forms the most substantial group of victims were infants under one year of age. The question whether this group of victims should be counted into the annual murder rate is a vexed one. 'Most scholars,' Monkkonen averred in a recent article, 'exclude infanticide and the murder of young children from their counts: consistency, not ethical judgement, determines this choice $^{14}$. In order to show the dominance of this crime one can take the murder verdicts recorded in the Liverpool Coroner's Court between 1852 and 1865. Children under one year of age accounted for $63 \%$ of the total homicide count of 182 . Interestingly children between 1 and 5 years accounted for fewer than $3 \%$ of verdicts. 
The $63 \%$ contrasts with the $80 \%$ of all coroners' reports of murders of infants in the 1860s in London, cited by Higginbotham ${ }^{15}$. This difference in the figures might be accounted for by the overzealousness of coroners with medical backgrounds in London compared to legally trained ones in Liverpool. The coroners from the latter city may well have been more inclined to advise juries to arrive at verdicts which were more descriptive of the cause of death rather than the definite legal judgement of murder, since the burden of imprecise evidence placed before the inquest would not have been able to carry the weight of such a verdict. If one examines the verdicts of the Liverpool coroners' juries over the period between 1852-1865 for children under one year we find the following: 'found suffocated', 'stillborn', 'accidentally smothered', 'whether stillborn or born alive no evidence', 'chance medley', 'want of attention after birth', 'exposure to cold', and 'cause of death unknown'. Such findings could well have hidden possible homicides and have almost certainly been interpreted differently in other areas of the country, especially in Middlesex where coroner Edwin Lankester appears to have been of the opinion that many 'accidental' infant deaths were homicides ${ }^{16}$.

Whilst Liverpool and Manchester do not appear to have such detailed reports as Glasgow, for example, on sudden infant deaths, Frederick Lowndes, the Liverpool coroner, analysed the city's inquests on new-born infants between 1869 and 1871. Of the total 127 inquests, murder verdicts were returned in 28 cases, whereas the remaining 99 cases of infant deaths were covered by the following headings: want of attention -19 cases, found dead -24 , still born -34 , and other verdicts -22 cases $^{17}$. He was under no illusion that such headings covered child murder. Quoting a Mrs Meredith, who visited Brixton Prison in 1869, in support of his supposition, Lowndes reported:

Many of them (inmates) killed more than one child. I discovered that there was a kind of sisterhood amongst them...I found a girl who became a mother at sixteen, and who was taught to kill her child. She fully understands the art, and would, in my opinion, practise it again, if she had an opportunity. In fact there are some women in the prison... who have quite a contempt for infant life, and who speak of their crime with a kind of triumph, being the subject of no shame whatever. The elder hands teach the young girls, and they consider it a mean thing to kill an infant in such a manner as to be found out ${ }^{18}$.

Even allowing for an element of Victorian sensationalism in the reported statement of Mrs Meredith, other evidence suggests that a number of unwanted children were murdered with the help of women experienced in such matters. In 1873, for example, a mother of a newborn infant, the mother's mother and a neighbour were discharged for the murder of the infant. The coroner's court had earlier reached a verdict of suffocation but were unable to provide evidence of how it was achieved ${ }^{19}$. Five years earlier a newspaper report cast light on the role of the midwife and the economics of burial. In this particular case the mother claimed she had attempted to attract a neighbour by knocking on the dividing wall but she had fainted just before her child was born. When a midwife eventually arrived the mother said she had not heard the infant cry and as a consequence she 'did not want a coroner's inquest over it'. The midwife obliged by certifying the child was a stillborn which would only cost $2 \mathrm{~s} 6 \mathrm{~d}$ to bury. The coroner's beadle, however, sensing some untoward practice, stopped the certificate and a post-mortem was carried out. The doctor conducting the examination opined that the child had been born alive "but had died from exposure and want of attention after birth'. The only outcome to this case was the censuring of the midwife for handing out a false certificate ${ }^{20}$. And if we accept Monkkonen's plea to dismiss such 
cases as these when considering murder rates, in the interest of consistency historians should ensure that they do just that. If we study Monkkonen's murder rate for nineteenth-century Liverpool we notice something rather strange concerning the crude murder rate of 27 for 1867-1868. It would appear on first sight that the city was in the grip of a killing spree but closer inspection reveals that of the 27 reported murders, 23 'were verdicts against persons unknown for the murder of infants found exposed'. Only four murders, in other words, should, under Monkkonen's directive, be used when calculating the city's crude murder rate. The 1867-68 murder rate for Liverpool can vary between $0.9 / 100,000$ if we base the calculations on 4 murders, but if we take 27 in the Head Constable's report the murder rate rises to a staggering 5.65/100,000.

11 If the Head Constable's Annual Reports for the 1860s are examined in a little more detail it becomes increasingly clear that there was a change in reporting practice, inasmuch as infanticide cases were bracketed under the murder heading. In 1865-66 six of a total of eight reported murders were found to be infanticides, and of the six reported murders for 1866-67 five were also for murder of infants. By 1869-70 nine of the 10 murders reported were infanticides. In all these years the finding of murder relied on the verdicts of the coroner's jury ${ }^{21}$. This would suggest that for a brief while there was a popular concern on this theme ${ }^{22}$. But given the wide variation in the figures for each of the years there appears to have been little consistency in the behaviour of the coroner's court jury, let alone the police. The annual police statistics only begin to list the murder of children under one year of age under a separate heading in the year ending 29 September 1878 thus allowing historians an element of consistency when calculating crude murder rates for Liverpool. Prior to that date, unless the head constable commented on the murders in his annual reports, the only way historians can separate murders of children from other murders is by leafing through the local press.

12 In the foregoing discussion the infant deaths did at least make it into the official documents and have left some kind of trace for historians to cradle within their quantifying and qualitative methods. However, the following discussion turns to cases and specific examples which were not, as far as I can discover, recorded as murders, manslaughters or, in some cases, concealment of births. Some show the dangers of accepting the coroners' juries' verdicts as clear-cut decisions. Many of them date from the 1870 s, a decade which I have examined in more detail than others, and, during which I have found 100 suspicious deaths reported in the local press, mostly in the Liverpool area. Not surprisingly 66 of these deaths related to infants under one-year of age. To place the above figures into some kind of perspective the Liverpool police reported 58 murders and 149 manslaughters during this decade. Whilst my sample for the 1870s only included three months of Liverpool newspapers in any one year, the figure of suspicious deaths, even allowing for the subtraction of infants, seems quite high.

13 In the case of infants and babies the most common inquest verdicts - suffocation or smothered - raised suspicions of foul play. A typical example of a suspicious case involved the death of the three-day-old illegitimate child of a woman named McCann who had had nothing prepared by way of baby clothing for the child. The circumstances of the birth too indicated that the child was anything but welcome. It was reported that a third party had sent for a midwife at the last minute, the latter remonstrated with the mother for her lack of preparation, to which she replied; 'It did 
not matter, the child would not live'. A day later the baby was clearly hungry and the mother was warned that it might die. 'And a good job too', she replied. Two days later the baby was dead. Although the coroner and the inquest jury found the case suspicious, the death was recorded as an open verdict ${ }^{23}$.

Even where the mother admitted to suffocating her newborn infant as in the case of 19year-old Louisa Brough in 1894, the jury decided her mind was unhinged at the time of her admission of her guilt and so acquitted her of murder, manslaughter and concealment of birth ${ }^{24}$. If any reader has doubts that suffocation was a cover for murder then the following case provides sufficient evidence of how mothers were able to kill their children. It concerned that of widow Mary Quinn whom the police caught in the actual act of smothering her new-born child. Unusually the police were not only close by but had had their suspicions aroused by Quinn's neighbours who had informed them that she was pregnant and close to confinement. They had suspected her of killing her previous baby in the spring of 1891 . When they broke into Quinn's room she was caught in the act of placing 14 bed irons on a mattress. On removing the irons and lifting the mattress from the bed, the police found a baby, already dead. A closer inspection of her room revealed a box with the remains of another child. Being caught red-handed in this case led to two murder charges against Quinn ${ }^{25}$.

Even from this distance few doubts remain that unrecorded murder or manslaughter had taken place in two further examples. First, in 1871 a Wigan woman, Ann Burns, overcome with guilt, admitted to the police to poisoning her stepfather, when he was ill, and then later informed them that she had also done away with two of her children 30 years previously and had claimed three lots of insurance. In none of the cases had the deaths raised any suspicions at the time. It is doubtful that these murders were added to the 1871 annual statistical returns, partly because the murdered stepfather was also the father to her two children and partly because she was committed insane when the truth finally came to light ${ }^{26}$. In an infamous case, which covered investigations in Tuebrook, Liverpool, Penrith in Cumberland, and neighbouring Westmorland, the remains of six children were discovered. The defendant, widow Elizabeth Kilbride, was quick to admit concealment which carried only a two-yearsentence as opposed to the death penalty for murder. Medical opinion was unable to state with a degree of certainty whether the infants had ever had an independent existence as the bodies had, in some cases, been up to 10 years in tin boxes. It was noted that in at least one case the body had a ligature tied tightly around the neck which suggested strangulation. In passing sentence Justice Manisty said; 'She had acted as a mother so inhuman that the case was almost without parallel, and in a manner in which no humane person - still less a mother of her own offspring - would have acted'. In considering whether she should have been tried for murder he commented, '...only the difficulties, technical more than substantial, arising from points of law and the rules of evidence, which rendered conviction for murder improbable', had prevented him from trying her on a capital charge. He had not the slightest doubt that in five of the cases she had resorted to violence. She was fortunate to escape with a sentence of two years and three months hard labour ${ }^{27}$.

In another notorious case, which made national news and was known as the Tranmere Baby Farmers case of 1879, John and Catherine Barnes were charged with the murder of three infants by gradual starvation. The two defendants were eventually found guilty of manslaughter of the three infants. However during the investigation it became evident 
that the three dead infants represented only the tip of an iceberg of covert homicides but the authorities had difficulty in tracking the couple's movements over the previous five years during which time they had also used a number of aliases. It was estimated that between 30 and 40 children had passed through their hands but, as the Birkenhead stipendiary magistrate argued; "much evidence might have been brought before the court which would have involved great expense to the country, Mr Moore the Treasury prosecutor properly listened to his (magistrate's) suggestion that the country should not have to pay for more witnesses than were absolutely necessary...'. In all 18 children were finally unaccounted for, and in passing sentence Lord Justice Brett said, 'You have been guilty of crimes, successive crimes, carried on for years from the vilest and most mercenary motives, each of which crimes was only a hair's breadth short of murder. Manslaughter is a crime which may be slight, but it may be and sometimes is, the next crime to murder'. They each received 20 years penal servitude ${ }^{28}$. Other suspicious deaths of infants include the three-day-old baby thrown from a train near Preston and those found with ropes and string tied around their necks. In one case the child had been dead for six to eight weeks when it was raised from the Leeds-Liverpool canal. Consequently medical opinion was reluctant to state the cause of death and so the jury returned an open verdict ${ }^{29}$.

In examining the deaths of children under one-year of age the question whether we count them in the same way that we count adult suspicious fatalities will remain a problem for historians. The Victorians, too, were unsure, especially in the 1860 s when infanticide was regarded as a national scandal. We have seen that, for a short while, sudden infant deaths inflated Liverpool's murder statistical returns. However infant killing appears to have receded in importance as a public concern and as an inflationary element in official murder statistics when infant killing was placed under its own separate heading by the 1870 s.

\section{Suspicious Deaths of Children}

The sudden and mysterious deaths of children, other than infants, appear to have been far less numerous than infants' killings. Moreover the investigations of theirdeaths presented the authorities with problems not too dissimilar to the ones faced when investigating the mysterious deaths of adults. Limitations in detection are evident in the case of the death of five-year-old Ellen Fairclough who was told by two young men to open her mouth into which they placed 'something that looked like white soda'. She and another playmate were told to swallow the poison. The boy vomited andrecovered whilst Ellen died. The police were unable to take their investigations further. The police were similarly frustrated in their investigation into the death of a six-year-old boy. Someone had placed a red-hot rivet down the back of his shirt. The coroner's jury returned an open verdict even though the case had the appearance of unlawful killing ${ }^{30}$.

Many of these limitations are apparent in a sad tale from 1892. Various narratives ranging from the innocent and accidental to the cruelty and horror of child murder can be constructed around the death of Ann, a three-year-old from one of Liverpool's backstreet courts in the north end of town. She was found dead, head first in a privy at 11.00 on an August night. She had been sent out to play, early that day, wearing goldplated earrings and some nearly new boots. Ann was last seen alive earlier that evening 
with a group of women. The police, who had initially suspected murder when her body was found, had, 24-hours later, altered their opinion because, in their words, they had no hard evidence on which to base any conclusions. The press too began to speculate that Ann's death was accidental and constructed a possible scenario in which someone had stolen Ann's earrings and boots and then shut her in the privy where she may have slipped and fallen head first into the closet where she remained stuck. The postmortem added further to the mystery, in as much as it revealed that she had recently eaten pickled onions. This fact confirmed to the parents that she must have been with a stranger. And like so many other inquests the jury was guided by the surgeons' findings that the death was due 'to gradual asphyxia'. But what shakes the modern-day reader is the final almost throwaway remark of the surgeon who remarked; 'they also found marks which led them to believe that she had been improperly dealt with', a euphemism for sexual interference. The police enquiries ended with an open verdict. So even if Ann had not been murdered she had been the probable victim of a robbery and sexual assault ${ }^{31}$.

of the 250 cases of sudden and mysterious deaths collected only twelve cases concerned children over the age of two. They represent the tip of an iceberg of child murder related to burial clubs and child life insurance. Rose cites the case of Thomas Moore of Stockport who was accused of murdering his two step-sons, aged eight and four and half years old. Their bodies were found floating in a canal. Although there was insufficient evidence to find Moore guilty the Liverpool assize Grand Jury presented a statement which claimed that burial clubs 'operate as a direct incentive to murder'. Although this led to a flurry of debate very little effective legislation was enacted during the remainder of the nineteenth century. The murder of insured children, other than infants, was not seen as a sufficiently pressing social problem ${ }^{32}$.

\section{Adult Male Victims of Suspicious Deaths}

Moving onto the subject of suspicious adult deaths, as one would expect from a port like Liverpool with a large itinerant population of sailors and emigrants, the desire to investigate some deaths was probably not very pressing, especially if the bodies had been dragged from the dock basins, the River Mersey or washed up along its shores. An open verdict was, for example, returned in 1875 on the body of an unknown 30-year-old male washed up with a wound in his side and marks on his throat ${ }^{33}$. It was not unknown for sailors to pitch dead colleagues overboard on leaving port. The authorities, arguably, thought any investigation of foreign and unknown seamen a waste of time and expense especially as they did not represent any kind of social threat. In addition there is, of course, the practical consideration of decomposition which not only made establishing the cause of death difficult it also ensured the speedy burial of the deceased. In what has to be an understated headline of 'suspicious death' in 1892 the Liverpool Mercury reported the discovery of a 40-year-old man in the docks with his pockets turned out and his arms tied to his side with strong cord. The following day the coroner's court returned a verdict of 'found drowned'. A similar verdict had been reached on the body of a black man dragged from Nelson Dock in Liverpool in 1871. It was also noted that he had a cut on his temple and bruising on his forehead. The numerous canals in the region also probably served as conduits for the disposal of dead 
bodies. Two men were found in the space of a week near Warrington, one in the Sankey Brook with a dislocated neck, the other in the Bridgewater Canal ${ }^{34}$.

A case for covert homicide or secret murder can be made for a group of victims, mainly adult males, found dead or unconscious in the streets with serious injuries usually to their heads. Obviously the act of falling, whilst drunk, onto hard stone flags or cobbles would have produced some fatalities. However a number of cases are worth highlighting insofar as they puzzled coroners then as much as they might puzzle historians now. Given the limitations of forensic medicine in the mid $19^{\text {th }}$ century it is unsurprising that such cases were left unresolved. There was, for example, the chemist's assistant who, according to the surgeon at the post-mortem, had received his head injuries from a blunt instrument, and that of a seaman, newly arrived in Liverpool from San Francisco found with wounds to his face and the back of his neck. In both cases the coroner's court verdict was 'died of injuries received, but no evidence' ${ }^{35}$. The most intriguing and mysterious possible murder and street robbery concerned a ironfounder, named Barber, who, with a group of allegedly sober friends, walked through the then popular Belle Vue Gardens, Manchester on their way to the railway station. When the party arrived at the station Barber was found to be missing but after a short and fruitless search the group returned by train to their home town in Derbyshire. Two days later Barber's body was found in the Rochdale canal and when dragged out, his pockets were empty and his watch missing. Further suspicion was raised as he had extensive bruising to his face. Whatever the police thought, the coroner's jury returned the rather anodyne verdict of 'found drowned'. And there the matter ended - presumably the trail was too cold for any successful detection ${ }^{36}$.

Male-on-male fights which resulted in fatalities carried a range of investigative problems for both the coroner and the police, not least if the victim and the alleged assailant were both drunk at the time of the killing. Criminal investigations could also be limited by the widespread perception that male violence was often construed as normative behaviour. In such circumstances and contexts deaths resulting from male brawls might be perceived as unfortunate accidents. If, however, there was a possibility of criminal charges being brought, both the coroner and the police closely investigated the chronology of the fight, who threw the first punch, who started the argument, what insults were thrown, was someone struck or kicked whilst lying on the ground, and so forth. In circumstances such as these a plea of self defence by the surviving combatant could be readily accepted ${ }^{37}$. In 1896 a man named Wilson died after a 'fair' fight with a neighbour named Duxbury. The two men had visited a coach builder and sought his permission to use his empty stable as a fighting ring where they fought, punched and wrestled for five rounds in front of a group of male neighbours. Subsequently they left by separate exits and went to their respective homes, where Wilson complained of an injury to his abdomen. The post-mortem revealed a ruptured abdomen, and all the witnesses at the coroner's court maintained that the fight had been fair. Although the coroner's jury returned a verdict of manslaughter, the police and stipendiary magistrate dropped all charges against Duxbury because the evidence suggested that the deceased had issued both the challenge to fight and had called him a 'coward'38.

24 A reluctance to connect the injuries to the possible cause of death was not unusual and further highlights the shortcomings of Victorian forensic medicine. This was evident in the following example of an inquest concerning a fatal fight between two drunken sailors. The coroner's court heard evidence that was surprising even by the standards 
of Victorian times because the doctor thought death might have been from natural causes. The coroner's jury returned an open verdict and their decision led to the survivor's discharge from court. It was less surprising that medical opinion was reluctant to link death with an assault in the case of 11-year-old Edward Shepherd who had been hit on the head by a Mr Linford. He had found the boy in his yard 10 months prior to the lad's death. The post-mortem revealed a fracture of the skull and an abscess on the brain immediately below the fracture. Given the time-lag between the attack and the boy's death the coroner's jury had no other option than to reach a verdict of 'died from injuries, but how they had been received there was no evidence to show', even though details of the former assault were presented to them ${ }^{39}$.

As with infanticide some adult male sudden deaths do not appear to have attracted close investigation from the police for a variety of reasons. Where men were found dead in the water or lying fatally wounded on city streets, the police may well have concluded that the discovery of culprits responsible for these deaths was impossible. Any investigation was, therefore, impractical even more so if the victim's identity was a mystery. Such cases appear to have escaped the annual homicide statistics drawn up by the policing authorities. In other cases traditional notions of male-on-male 'fair' fights still lingered on in the late nineteenth century. Consequently the surviving combatant could escape even a lesser charge of manslaughter.

\section{The Disreputable and the Domestic: Adult Female Victims of Suspicious Deaths}

26 Cases of domestic violence and male violence to women which ended fatally provided 51 per cent of my sample of suspicious adult deaths. Some of the inquest reports highlighted a practice which was not uncommon among coroners and one which has already been alluded to, namely their acceptance that death may have been possibly due to the medical condition of the deceased rather than any violence she might have received. In the case of 46-year-old widow Elizabeth Jones who was seen fighting a man the post-mortem on her body showed death from liver disease probably accelerated by violence. The man was, as a consequence, released from police custody. Thirty-fouryear-old Ann Ford who had, according to the post-mortem, died from tetanus, had received a head injury in a fight. Other women and men found dead at the bottom of cellar steps (cellar steps in Liverpool were open without guard-rails) shortly after rows raised the question for police and coroners; were they pushed or did they fall? Ann Gilligan, an 'old faggot', was pushed down some steps by a man named Wilson, a clerk of 'respectable appearance'. She fractured a leg and died. The official finding for the cause of death was diseased internal organs which led to Wilson's trial for manslaughter being treated like a common assault ${ }^{40}$.

All the female victims cited so far possessed something in common, something which newspapers emphasised in their reports, namely their disreputable lifestyles or reputations. Jones was 'slovenly and intemperate' in her habits; Ford was separated from her husband and a 'heavy drinker with eight previous convictions'; and Gilligan was 'in drink' at the time of her fatal row. None of these women was portrayed as a martyr to femininity and domesticity. They were transgressive females who fell far short of any feminine ideal as did, indeed, prostitutes. In one such case from the 1890s, an open verdict was returned on the death of Mary Ann Tyrrell, formerly a Dublin shop 
assistant. After an alcoholic fit she was transferred from a police cell to the workhouse hospital where she told friends that she had been beaten. The post-mortem examination discovered bruises on her arms, legs, eyes and the right side of her body. Her legs and thighs, it was reported, "being almost completely covered with bruises' ${ }^{41}$.

One problem peculiar to domestic killings was that such events often took place behind closed doors in which witnesses, if there were any, may have been young children. In the case of Hannah Allen who had cohabited with Alfred Robertson for 17 years, an 11year-old errand boy claimed to have seen her being assaulted. He informed the inquest that, on knocking at the door and getting no reply, he had looked through the keyhole. Robertson was, he claimed, knocking Allen's head against a wall and slapping her face. Later, after she had picked up a knife, he set two dogs onto her. When the door was finally opened she sported two black eyes. Robertson, who was known to the police as a 'sober and steady man', claimed she was drunk and had fallen in the backyard. He admitted only to slapping her once 'with an open hand'. When the inquest jury reached a verdict of 'Death from violence, but not sufficient evidence to show how caused', Robertson was arrested. Days later he was discharged as the only witness was 11-yearsold and the police believed he could not have seen everything he said he saw through the keyhole ${ }^{42}$. Children were not generally considered credible or reliable witnesses, especially if they had spent some time alone in the company of the prime suspect before the police were involved. When the police found the wife of Hugh M'Cann dead on her bed with a cut eye and several bruises on her body they were told by the deceased's sister that she was a drunken woman who often quarrelled with her husband. As the chief witness he said that his wife had told him that she had fallen from the back wall of the house and hurt herself. One of his children backed up this story but M'Cann had immediately 'left Liverpool' ${ }^{43}$. In another case a daughter changed her story of what she had witnessed. Initially she had said that her father had beat and kicked her mother but at the inquest she informed the court that she had never seen her father 'strike' her mother. Other witnesses provided evidence of a long and violent relationship between the couple. Because Mary Ann Slattery drank heavily and had an 'enormous white liver' at the time of her death the jury found death to be by natural causes, 'accelerated by gross neglect and violence, but by whom there was no evidence to show ${ }^{44}$.

The questions of what witnesses saw or were willing to relate to enquiries were of vital importance and relevance to the outcomes. Witnesses could be either partial or highly selective in what they chose to relate. This would appear to be the case in the enquiry into the death of 16-year-old unemployed domestic servant named Mary Quirk who, on returning tipsy with a couple to their house, was followed up to the garret by the husband. He in turn was followed up the stairs by his presumably suspicious wife. Raised voices were heard by those downstairs and then the sound of screaming as Quirk fell from the garret window. The jury's verdict was that Quirk had died from injuries received in the fall from the window, "but how she came to fall there was not sufficient evidence to show'. This was based on the husband's and wife's evidence that she had jumped. One can think of at least one alternative scenario of how Quirk came to be falling to the yard below, and one senses that the jury was similarly suspicious but powerless to come to any other conclusion than the one at which it arrived ${ }^{45}$.

30 The time lag or lapse between an assault and death was often favourable to a suspect when it came to a police or coroner's investigation. Margaret M'Garvey died of fever 
within three hours of being admitted to a Liverpool hospital. Two witnesses reported seeing her being struck in the face and kicked several times by her husband a week previously. Although the coroner's jury was critical of the husband he was merely censured by the county coroner. A similar outcome occurred at Preston where the coroner censured Archibald Titterington at the end of an inquest on the body of Louisa Walsh, a single woman, who died of tetanus and inflammation of the lungs after being seriously burnt. From the evidence at the inquest it transpired that she and Titterington, a married man, were having an illicit liaison, which two women neighbours happened upon. He left the upstairs room hurriedly and shortly afterwards Louisa ran past 'all on fire, and screaming "Oh save me! Save me! I'm on fire! Put me out!". A neighbouring landlord, hearing the screams, ran out of his pub and saw 'a large flame spinning in a circle in the middle of Heatley-street. The flames rose as high as the top of the lamp post, quite two yards above the head of the deceased.' In her dying deposition Louisa alleged that Titterington had thrown a lighted candle at her which set the net on her head on fire and subsequently the rest of her garments. Doubts can be raised as to the veracity of her deposition insofar as there was an alleged 10-minute time gap between Titterington leaving the house and Louisa emerging in flames. However both the coroner and the jury thought Titterington 'was deserving of censure' when arriving at an open verdict ${ }^{46}$.

Recent research by Martin Wiener suggests that male violence towards women was increasingly stigmatized during the nineteenth century. Men, he argues, were increasingly prosecuted for their brutal treatment of women, even when the women were considered to be 'dissipated' or 'immoral' ${ }^{47}$. This could result in either murder or manslaughter charges if the victim was killed. However the few examples cited above suggest there could still be problems in bringing murder charges in domestic violence cases. First, the actual killing was often not witnessed by other adults, and second, if the woman was known to have been a heavy drinker this could count against her either morally or during the post-mortem when diseased organs were uncovered.

\section{Conclusion}

The examples which have been cited in this article indicate that there were numerous categories of suspicious deaths. These are not just suspicious to historians in the twenty-first century but were also suspicious to police and coroners at the time. It could be that criminal investigations were not pursued for a variety of reasons. It has been noted that Taylor's favoured explanation, expense, was mentioned explicitly in the case of the Tranmere Baby Farming case. Other possible explanations should include the lack of forensic evidence and the capacity to interpret such evidence where it did exist. The difficulty of determining causality was a problematic issue in general when identifying covert homicides, and one which was especially important when connecting injury to death. Finally medico-legal and societal conventions, especially when dealing with infants, who were by far the largest group of suspicious deaths, should also be included as possible explanations for under-recording homicides.

The verdicts of manslaughter and murder were subject to prevailing local, social, cultural attitudes and practices just as they are today with, for example, euthanasia. Back in the nineteenth century these norms might well work in favour of male suspects who had killed opponents in male-on-male 'fair' fights. The same attitudes could work 
in favour of men with reputations as sober and steady workers in cases where their female partners had died under sudden and mysterious circumstances. In the case of domestic killings, the deceased's reputation was scrutinised, weighed against that of the male partner and killer and judged harshly if she failed to measure up to prevailing middle-class values of womanhood. One is almost left with a kind of league table of sudden and suspicious deaths in which those at the bottom, infants - strangers and foreigners - prostitutes and low-born women, many of Irish descent, with alcoholic problems - men in fights and lunatics in asylums, were least worthy of detailed enquiry and further police investigation, whilst adults of higher social standing guaranteed vigorous enquiry ${ }^{48}$. It is, perhaps, worth noting that in all the cases cited in this article the victims were, in terms of social status, working class. Whether this is coincidental or a true reflection of the pattern of such covert homicides is impossible to say. However it would be erroneous to believe that the middle classes never indulged in such practices, it may just be that they were better able to hide such killings. Shimmin, the Liverpool journalist, claimed that the smothering of infants was 'rife' among the middle and upper classes but fails to provide evidence of such practices ${ }^{49}$.

The evidence from the North West would tend to support Taylor's conclusion that, from the 1880s, 'most murders and suspicious deaths went uninvestigated' by the police. Indeed, the examples presented in this paper suggest that this was also the case prior to $1880^{50}$. The verdicts reached in the coroners' courts may have masked a multitude of crimes, not least filtering out possible murders which then failed to be recorded in the annual official criminal returns. However the reasons for the lack of investigation encompass many more factors than the lack of money made available for such enquiries. It could be argued that there were other rational and practical issues which needed to be considered by the various investigative agencies, not least whether there was a realistic chance of proving a crime had in fact occurred or whether a culprit could be tracked down. In the final analysis the police may also have had to consider whether the victim's death threatened to undermine the well-being and fabric of society. We have seen that the vast majority of the fatalities of women and children took place behind the closed doors of backstreet slums far from the gaze and concern of the middle classes. All of these considerations led to the undercounting of homicides in England and Wales.

Whilst the findings of this article support Taylor's conclusion that many murders went uninvestigated, what do these uncounted murders tell us about the reported decline in violence being experienced by British society towards the end of the nineteenth century? Do they, for example, invalidate and undermine the statistics on which historians rely to make the case for the decline? And where do these missing homicides, especially those involved in domestic disputes and male-on-male fights, fit into the arguments put forward by Wood, Emsley and Wiener? All three authorities have suggested that nineteenth-century society tolerated violence less and less, and, as a consequence, violent actions were increasingly prosecuted. Wiener, for example, argues persuasively that the killing of 'unfaithful' wives became increasingly stigmatised $^{51}$. Emsley and Wood have noted that male-on-male violence, so frequently tolerated and accepted as conventional in the first half of the nineteenth century, was, in the second half of the century, considered barbaric, unEnglish and only something practised by the poorest social groups ${ }^{52}$. Such changes in attitudes, one would have thought, might have led to an eventual fall in the number of suspicious and unreported homicides and a concomitant rise in prosecutions. It is impossible, however, to quantify 
the number of suspicious and unreported homicides but it is reasonable to speculate that there had been many suspicious deaths throughout the nineteenth century and earlier. Furthermore their numbers were decreasing towards the end of the nineteenth century for the reasons put forward by Emsley, Wiener and Wood. That being so, then the long-term decline in homicides, argued by Eisner, Gatrell and Gurr, and supported by their analysis of the criminal statistics, offer a reasonably accurate picture of that downward trend ${ }^{53}$.

There are, however, two issues relating to the national statistics that need to be borne in mind by historians. First, the homicide rate per 100,000 of the population is underestimated. The 'dark figure' for homicide was much greater than many historians have assumed but it is impossible to estimate its size or its relation to the real level of homicide. Second, historians should recognise that infanticide presents a problem in terms of consistency of quantification and methodology. Some historians have, on occasions, included a number of infanticide cases in the national murder count prior to 1878. Furthermore the sudden deaths of infants have always created forensic challenges which remain unresolved to this day ${ }^{54}$. In other words how do historians count infanticide cases - if indeed their numbers can be quantified - and should they be included in the national homicide figures? Afterall infants represented the largest group of homicide victims. Ultimately it might be possible to accept both Taylor's proposition that many murders went unrecorded, and the research of Gatrell, Gurr, and Eisner which argued that there was a downward trend in the homicide statistics in the second half of the nineteenth century.

\section{BIBLIOGRAPHY}

Archer, D., Gartner, R., Violence and Crime in Cross National Perspective, New Haven, Yale, 1984.

Archer, J. E., "Men behaving badly"?: masculinity and the uses of violence, 1850-1900, in D'Cruze, S. (Ed.), Everyday Violence in Britain, 1850-1950, Harlow, Longman, 2000, pp. 41-54.

Behlmer, G. K., Deadly motherhood: infanticide and medical opinion in mid-Victorian England, Journal of the History of Medicine and Allied Science, 1979, 34, pp. 403-427.

Bickerton, T. H., A Medical History of Liverpool, London, John Murray, 1936.

Brabin, A., The Black Widows of Liverpool: A Chilling Account of Cold-blooded Murder in Victorian Liverpool, Lancaster, Palatine Books, 2003.

Campbell, J., Laxton, P., Homicide and Manslaughter in Victorian Liverpool: A Research Report, Dept. of Geography, University of Liverpool, 1997.

Cockburn, J. S., Patterns of violence in English society: homicide in Kent 1560-1985, Past and Present, 1991, 130, pp. 70-106.

Collins, W., The Woman in White, Oxford, Oxford University Press, 1996 [originally published 1861].

Eisner, M., Modernization, self-control and lethal violence: the long-term dynamics of European homicide rates in theoretical perspective, British Journal of Criminology, 2001, 41, pp. 618-638. 
Eisner, M., Long-term historical trends in violent crime, Crime and Justice, 2003, 30, pp. 83-142.

Emmerichs, M. B., Getting away with murder?, Social Science History, spring 2001, pp. 93-100.

Emsley, C., Hard Men. The English and Violence since 1750, London, Hambledon and London, 2005.

Gatrell, V. A. C., The decline of theft and violence in Victorian and Edwardian England, in Gatrell, V. A. C., Lenman, B., Parker, G. (Eds), Crime and the Law: A Social History of Crime in Western Europe since 1500, London, Europa, 1980, pp. 238-337.

Glasgow, G. H. H., The campaign for medical coroners in nineteenth-century England and its aftermath: a Lancashire focus on failure (part 1), Mortality, 2004, 9, pp. 150-167.

Gurr, T. R., Historical trends in violent crime: a critical review of the evidence, Crime and Justice: an Annual Review of Research, 1981, 111, pp. 295-353.

Havard, J. D. J., The Detection of Secret Homicide. A Study of the Medico-legal System of Investigation of Sudden and Unexplained Deaths, London, Macmillan, 1960.

Higginbotham, A., "Sin of the age": infanticide and illegitimacy in Victorian London, Victorian Studies, spring 1989, pp. 319-337.

Lowndes, F. W., Infanticide in Liverpool, National Association for Promotion of Social Sciences, 1872-1873, pp. 397-412.

Monkkonen, E. H., Diverging homicide rates: England and the United States, 1850-1875, in Gurr, T. R. (Ed.) Violence in America. Vol. 1 The History of Crime, 1989, Newbury Park, CA., Sage, pp. 80-101.

Monkkonen, E., New standards for historical homicide research, Crime, History and Societies, 2001, 5, 2, pp. 5-26.

Morris, R. M., Lies, damned lies and criminal statistics in England and Wales, Crime, History and Societies, 2001, 5, 1, pp. 111-127.

Philips, D., Crime and Authority in Victorian England: the Black Country 1835-1860, London, Croom Helm, 1977.

Rose, L., Massacre of the innocents: Infanticide in Great Britain 1800-1939, London, Routledge \& Kegan Paul, 1986.

Russell, J. B., Report upon Uncertified Deaths in Glasgow by the Medical Officer of Health, Glasgow, 1876.

Sharpe, J. A., The history of violence in England: some observations, Past and Present, 1985, 108, pp. 206-215.

Stone, L., Interpersonal violence in English society 1300-1800, Past and Present, 1983, 101, pp. 22-33.

Taylor, H., Rationing crime: the political economy of criminal statistics since the 1850s, Economic History Review, 1998, LI, 3, pp. 569-590.

Walton, J. K., Cox, A. (Eds), Low Life and Moral Improvement in Mid-Victorian England: Liverpool Through the Journalism of Hugh Shimmin, Leicester, Leicester University Press, 1991.

Watson, K., Poisoned Lives: English Poisoners and Their Victims, London, Hambledon Continuum, 2004.

Wiener, M. J., Men of Blood: Violence, Manliness, and Criminal Justice in Victorian England, Cambridge, Cambridge University Press, 2004.

Wood, J. C., Violence and Crime in Nineteenth-Century England: the Shadow of Our Refinement, London, Routledge, 2004. 


\section{NOTES}

2. Gurr (1981); Gatrell (1980); Stone (1983); Sharpe (1985); Cockburn (1991). See also Eisner (2001) and (2003) for more recent studies which examine long-term decline in violent crime in a number of countries.

3. Taylor (1998).

4. Ibid., Previous studies of homicide tended to measure the crime in rates per 100,000 of the population. Taylor, on the other hand, examined the annual homicide totals as published in Criminal Statistics.

5. Morris (2001, p. 118). In a brief survey of official homicide figures for seven European countries between 1900-1939 the annual number of killings varied much more widely than that of England and Wales. In the case of five countries, namely Germany (to 1930), Hungary (to 1938), Italy, Norway and Scotland the majority of years lay outside the $20 \%$ variant of the respective national average number of cases, whereas in the case of England and Wales only $7.5 \%$ of the years lay outside the $20 \%$ variant; see Archer, Gartner (1984).

6. In addition to the articles already cited above see Emmerichs (2001); Monkkonen (2001). Liverpool's police surgeon, F.W.Lowndes, argued that coroners should be appointed from members of the medical profession, not the legal profession as 'too many cases of poisoning were put down as visitations of God.' See Bickerton (1936, p. 148).

7. Liverpool newspapers were consulted at the Liverpool Record Office(LRO), for Manchester papers, Manchester Central Library. Police annual returns are bound in the annual Proceedings of the Council, H352 cou, held at LRO and Manchester Local History Library and Archive, Liverpool Coroner's Registers 1852-65, 347 COR 1, LRO.

8. Philips (1977, p. 253).

9. See Liverpool Mercury, 3 February 1893, which reported that the business of the coroner's court was dealt with 'remarkable dispatch'; Havard (1960).

10. Figures extrapolated from the Liverpool Coroner's Court Register, 1863, and the Liverpool Head Constable's annual returns for 1862-1863, 1863-1864, H352cou, LRO.

11. Proceedings of the Council, Head Constable's Annual Return 1865-1866, p. 499. The emphasis is mine.

12. Proceedings of the Council 1864-1865, p. 463. The emphasis is mine.

13. Liverpool Head Constables' Returns for the 1860 s bound in the Proceedings of the Council.

14. Monkkonen (2001, p. 9).

15. For the number of infanticides in Liverpool see Campbell, Laxton (1997), a report commissioned by E. Monkkonen. I am grateful to the late Prof. Monkkonen for allowing me to use this document. The same information can be extracted from the registers at 347 COR 1, LRO. Higginbotham (1989). Rose (1986, pp. 38-39), makes comparisons between Liverpool, London and Manchester.

16. In 1862, prior to Lankester's appointment as coroner of Central Middlesex, there were seven cases of infanticide in that area of London. A year later the infanticide cases had risen to 40 . See Behlmer (1979, pp. 403-427). See also Glasgow (2004).

17. For Glasgow see Russell (1876), Edinburgh University Library, Special Collections, SC 5964. I am grateful to Chris Williams for bringing this report to my attention. Lowndes (1872-1873, p. 397) which lists the inquest verdicts between 1869-1871.

18. Ibid., p. 400.

19. Liverpool Mercury,26 November 1873.

20. Liverpool Mercury, 16 December 1868.

21. See Liverpool Head Constable's returns for the 1860s, especially 1867-1868, p. 465; Monkkonen, (1989, table 3.1, p. 86). 
22. Liverpool Mercury,14 April 1868 which reported that 'cases of infanticide have become so frequent in Liverpool of late that Mr Clarke Aspinall, the borough coroner, communicated with Mr G. Hardy, the Home Secretary, on the subject.' The latter 'authorised' the coroner to offer rewards for information that would lead to the arrests and prosecutions of the guilty parties.

23. Liverpool Mercury, 18 May 1878.

24. Liverpool Mercury,24 November 1894.

25. Liverpool Mercury, 4 February 1893.

26. Liverpool Mercury, 3 July 1871. In the case of Mary Whiteside of Longridge near Preston, it was reported that her husband and two of her children, all of whom died in separate incidents in 1878, were members of the Prudential Assurance Society, Liverpool Mercury,18, 22 and 27 November 1878. It was recognised by police, insurance officials and civil servants that there were some attempts to defraud insurance and assurance companies. Even Wilkie Collins alluded to the practice 'And murder will out...,will it? Ask Coroners who sit at inquests in large towns if that is true....Ask secretaries of life-assurance companies, if that is true....', (1996, pp. 236-237). See also Brabin (2003) for a detailed account of the infamous Flanagan and Higgins, Watson (2004).

27. Liverpool Mercury, 1, 5, 12, 22, and 23 February 1877.

28. Liverpool Mercury,1, 2, 300ctober 1879.

29. Liverpool Mercury,13 February 1877, the child was found between Leyland and Preston; ibid., 14 October 1881. In another case two fully grown female children were discovered in St Domingo's Pit, Everton. 'Upon each of the bodies', it was reported, 'string was fastened to the neck, the cords having been very probably placed there to produce strangulation', Manchester Courier supplement, 24 April 1880.

30. Liverpool Mercury,7 March 1862; ibid.,16 May 1872.

31. Liverpool Mercury, 4, 5, 6, and 18 August 1892. In another case which caused great 'indignation' a four-year-old girl died shortly after being sexually assaulted on her way home from school in Crumpsall, Manchester. The assailant, a man named Gouth, who had committed similar crimes in the neighbourhood, was initially charged with murder and criminal assault. The post-mortem on the girl, however, concluded that death was due to inflammation of the brain, produced by tuberculous deposit'. The coroner's jury reluctantly returned a verdict of death from natural causes, Manchester Courier, 23 and 24 May 1870.

32. Rose (1986, p.145; pp. 136-158).

33. Liverpool Mercury,15 October 1875; Emmerichs found many suspicious drownings in the River Thames (2001, p. 96).

34. For the body tied up see Liverpool Mercury, 7 and 8 January 1892; the body of a black man see Liverpool Mercury,12 July 1871; for the two canal cases see Manchester Courier,7 and 17 June 1887. Interestingly one body a week on average is retrieved from the River Thames by the police. Although modern pathology techniques allow the coroner and police to determine whether persons were alive when they entered the river, they still continue to have trouble determining whether a murder has occurred, consequently open verdicts are still most commonly returned by coroners' courts, Guardian G2, 15 December 2004.

35. Liverpool Mercury,2 July 1870 and 20 November 1872.

36. Liverpool Mercury, 14 October 1879.

37. Excellent research on male-on-male fights has been published by Emsley (2005); Wiener (2004); Wood (2004).

38. Liverpool Mercury,10 and 17 July 1896. This case and others are cited in my chapter on male violence, Archer (2000, pp. 41-54).

39. In the case of the fatality involving a sailor who appeared to have been stabbed, no one, not even the deceased in his dying deposition, witnessed the use of a knife. Medical evidence also suggested other additional causes for the sailor's death, Liverpool Mercury, 11, 12, and 15 August 1879. For the case involving Shepherd see Liverpool Mercury, 3 April 1865. 
40. For the Jones case see Liverpool Mercury,17 April 1876; Ford see ibid.,1 November 1872; Gilligan see ibid.,19 December 1866.

41. Liverpool Mercury,29 September 1898; ibid.,9 and 10 January 1896 for the mysterious death of a prostitute in a Manchester warehouse. See also Wiener (2004, especially chapters 5 and 6, pp. 170-239). where he examines the killing of 'Bad Wives'.

42. Liverpool Mercury, 8 and 13 November 1894.

43. Liverpool Mercury,18 August 1879. See also the case of John Wright who was tried for the murder of his wife Henrietta who had died from a ruptured spleen inflicted during a quarrel with her husband. The newspaper reported that the "quarrel was not witnessed by any other person except the son of the parties, a lad of 12 , and he said distinctly that the deceased woman struck her husband and then slipping upon some quills fell heavily against a chair'. Wright was acquitted, see Manchester Courier,29 January 1886.

44. Liverpool Mercury,28 and 29 October 1881.

45. Liverpool Mercury,4 October 1879. See also the report on the inquest on Emma Twist who died of erysipelas. Her family was convinced that she had been the victim of her husband's violence, whereas the Twist family argued that she had slipped and fallen on a broken jug. The jury returned a verdict of death from injuries accidentally received, Liverpool Mercury,4 September 1878.

46. For M'Garvey see Liverpool Mercury,16 August 1880; for Walsh see Manchester Courier, 9 December 1885.

47. Wiener (2004, pp.170-239).

48. I have examples of mysterious deaths in mental asylums, Liverpool Mercury,12 August 1892 and 9 November 1872. In the former case an inmate of Rainhill Asylum near St.Helens, was found with fractured ribs. In the latter case at Haydock Lodge, inmate William Lord died from injuries to his chest, ribs, and legs. He was also found to have a black eye and bruising over the body. Before he died he had told his wife that 'some of the patients and one of the attendants had abused him'. A subsequent enquiry into his death had concluded that Lord had not been ill-used by any attendants and that another patient named Booth, who had been found kneeling on him a month earlier, 'had since died'.

49. Walton, Cox (1991, p.143).

50. Taylor (1998, p. 588).

51. Wiener (2004).

52. Emsley (2005); Wood (2004, pp. 70-147).

53. Havard argued that prior to the nineteenth century no sudden deaths were investigated unless there was 'manifest evidence' of violence. 'This meant...that the majority of cases of murder...or other "secret" methods of killing went unrecognised' (1960, pp. 38-39).

54. As recently as April 2004 the Foundation for the Study of Infant Deaths reported that 30 to 40 under one-year-olds might be victims of covert homicide in England and Wales every year, Guardian, G2, 22 April 2004.

\section{ABSTRACTS}

By examining what Victorian newspapers headlined 'mysterious' or 'suspicious' deaths, this article argues that some of these deaths in the north west of England escaped the official 
statistics for homicide and, in particular, murder. In addition it is possible to identify cases which were downgraded to either manslaughter or assault, and these too may, as a result, throw light on cultural attitudes towards violence, not least the toleration and acceptance of certain forms of violence. Such 'smoking-guns' may partly explain why the official national statistics for murder remained low. This article also examines the victims of this unprosecuted violence and puts forward explanations as to why such cases were either downgraded or else ignored entirely by the policing authorities and the judicial system. It is argued here that certain groups within society, namely infants, foreigners and female partners, made up a substantial number of the victims whose deaths were ignored by the authorities. When issues of age, nationality, gender and the social status of the deceased are taken into consideration, it becomes clear that murder is not an unequivocal legal absolute. Rather it was a complex social construct.

Cet article analyse ce que la presse victorienne qualifiait de mort « mystérieuse " ou " suspecte » et soutient que, dans le nord-ouest de l'Angleterre, certains de ces décès échappaient à la statistique officielle des homicides, et en particulier des meurtres. En outre, on peut détecter des affaires qui ont été requalifiées en homicide involontaire ou en coups et blessures. Tous ces cas éclairent les différences d'attitudes à l'égard de la violence, et en particulier la tolérance ou l'acceptation de certaines de ses formes. Ils expliquent peut-être aussi le niveau peu élevé des meurtres dans les statistiques nationales. L'auteur examine également les victimes de ces violences non poursuivies et propose une explication à la minoration ou à l'ignorance de ces affaires par les autorités policières et judiciaires. Lorsqu'on prend en considération l'âge, la nationalité, le sexe et le statut social des défunts, il est clair que la notion de meurtre n'a pas un caractère absolu et sans équivoque au plan juridique, mais constitue plutôt une construction sociale complexe.

\section{AUTHOR}

\section{JOHN E. ARCHER}

Tarleton, UK - Preston PR4 6UU, archerj@edgehill.ac.uk

John E. Archer retired from Edge Hill University in 2003. He is currently an honorary research fellow of that institution. His publications include: 'By a Flash and a Scare': Arson, Animal Maiming and Poaching in Norfolk and Suffolk 1815-1870, Oxford (OUP), 1990; Social Unrest and Popular Protest in England 1780-1840, Cambridge (CUP), 2000. Evidence cited in this article is based on material drawn from the project 'Violence in the North West with Special Reference to Liverpool and Manchester 1850-1914', funded by the Economic and Social Research Council as part of the Violence Research Programme. This article is an extended version of a paper presented to the History of Violence Conference, Liverpool, 2001. I wish to extend my thanks to research project officers Jo Jones, David Orr and Carol Lewis-Roylance, and to Alyson Brown and Andrew Davies for their helpful comments. 